\title{
FEDERAL VENUE FOR UNINCORPORATED ASSOCIATIONS: PROBLEMS AND SUGGESTIONS
}

One of the more perplexing problems which arise with respect to the general venue provisions of the Federal Judicial Code $^{1}$ is the determination of the manner in which the statute applies to unincorporated associations. The attendant difficulties presented by reason of the ambivalence of the law regarding such associations as jural entities for some purposes but as mere aggregates of individuals for others are rendered apparent by the venue issues raised in Portsmouth Baseball Corporation v. Frick. ${ }^{2}$ In that case a diversity suit was brought in the Federal Court for the Southern District of New York by a Virginia corporation against the National and American Leagues of Baseball Clubs, botll of which are unincorporated associations, and others. Defendant leagues moved for an order dismissing the action against them on the ground that venue was improperly laid. They contended that in a diversity suit an unincorporated association must be sued either in the district of the defendant association's principal place of business or in the district of plaintiff's residence, ${ }^{3}$ and that the Southern District of New York met neither of these requirements. The court held, however, that an umincorporated association could be sued not merely at its principal place of business but also in any other district where it was doing business, and, accordingly, that the action could be maintained against the associations in New York because they were doing business there. ${ }^{4}$

The questions suggested by this decision are many-sided and intricate: Is the unincorporated association to be characterized as a jural entity for venue purposes? If so, how is its place of residence to be determined? Are these questions referrable to state or to federal law? May the answers vary depending upon whether the suit is under the court's federal question jurisdiction or is based on diversity of citizenship? It is the purpose of this

128 U.S.C. \$ 1391 (1952) provides:

"Venue Generally.

"(a) A civil action wherein jurisdiction is founded only on diversity of citizenship may, except as otherwise provided by law, be brought only in the judicial district where all plaintiffs or all defendants reside.

"(b) A civil action wherein jurisdiction is not founded solely on diversity of citizenship may be brought only in the judicial district where all defendants reside, except as otherwise provided by law.

"(c) A corporation may be sued in any judicial district in which it is incorporated or licensed to do business or is doing business, and such judicial district shall be regarded as the residence of such corporation for venue purposes.

"(d) An alien may be sued in any district."

Subsections (a) and (b) are substantially the same as the general venue provisions in the previous judicial code, 28 U.S.C. $\$ 112$ (1946), but subsection (c) is an innovation.

2132 F. Supp. 922 (S.D.N.Y. 1955).

328 U.S.C. $₹ 1391$ (a) provides that diversity suits may be brought "only in the judicial district where all plaintiffs or all defendants reside."

428 U.S.C. $\$ 1391$ (c) provides that "a corporation may be sued in any judicial district in which it is incorporated or bicensed to do business or is doing business ...." (Emphasis added.) The court in Frick said that this was applicable to unincorporated associations as well. 
comment to analyze the problems posed by these questions and to suggest some possible solutions with an eye to arriving at a logical venue classification for unincorporated associations. No attempt will be made, however, to deal with the related problems which arise after the classification has been made. 5 As a practical matter the discussion throughout will consider the unincorporated association as defendant rather than plaintiff. ${ }^{6}$

THE UNINCORPORATED ASSOCIATION AS A JURAL ENTITY

\section{For Purposes of Jurisdiction}

If a cause of action is based on federal law and meets the normal jurisdictional requirements such as proper service of process and jurisdictional amount, the fact that the defendant is an unincorporated association presents no additional jurisdictional problems. However, if the suit is based on diversity of citizenship, the jural character of the defendant association becomes pertinent. Under 28 U.S.C. $\$ 1332$ the federal district courts acquire jurisdiction only if there is complete diversity of citizenship between all of the parties plaintiff and all of the parties defendant. ${ }^{7}$ For purposes of jurisdiction, although corporations long have been regarded separate and apart from their stockholders as residing in their state of incorporation, ${ }^{8}$ the typical unincorporated associations known to American law, such as partnerships and labor unions, have not been similarly personified. When a diversity action is brought against such an association, the existence of jurisdiction must be determined in the light of the citizenship of all asso-

5 One example is the conceptual problem of "doing business" which is the criterion for residence of corporations under $\S 1391$ (c) and may be the test for obtaining service of process on a foreign corporation under FED. R. CIv.P.4(d). Are the same tests applicable in both situations? Is the question referable to state or federal law? What are the due process limitations of the Constitution? See Barrett, Venue and Service of Process in the Federal Court-Suggestions for Reform, 7 VAND. L. REv. 608 (1954); Note, 30 IND. I.J. 324 (1955).

6 For the purposes of litigating capacity and jurisdiction it should make no difference whether the association is a defendant or plaintiff-with the possible exception of diversity suits in the few states that have accorded litigating capacity to the association as defendant only, e.g., Cad. Code Civ. Proc. \$ 388; see Kadota Fig Assn. v. Case-Swayne Co., 73 Cal. App.2d 796, 167 P.2d 518 (1946); Note, 35 CaIrF. L. Rev. 115 (1947). However, since $\S 1391$ (c) may be limited to defendant corporations, it is convenient to direct the whole discussion accordingly.

Actually, the applicability of $\$ 1391$ (c) to plaintiff corporations is a disputed point. Southern Paperboard Corporation v. Umited States, 127 F. Supp. 649 (S.D.N.Y. 1955) ; Hadden v. Barrow, Wade, Guthrie \& Co., 105 F.Supp. 530 (N.D. Ohio 1952), and Freiday v. Cowdin, 83 F.Supp. 516 (S.D.N.Y. 1949), leld \$ 1391(c) applicable to plaintiff corporations, whereas Chicago \& North Western Ry. Co. v. Davenport, 94 F.Supp. 83 (S.D. Iowa 1950), reversed on other grounds, 95 F.Supp. 469 (S.D. Iowa 1951), held otherwise. See United Merchants \& Manufacturers v. United States, 123 F.Supp. 435 (M.D. Ga. 1954) ; Note, 28 IND. L.J. 256 (1953).

728 U.S.C. $\$ 1332$ (1952) ; Treinies v. Sunshine Min. Co., 308 U.S. 66, 71 (1939); Salem Co. v. Manufacturers' Co., 264 U.S. 182, 189 (1924) ; Strawbridge v. Curtiss, 7 U.S. (3 Cranch.) 266 (1806) ; Schatte v. International Alliance, Etc., 84 F. Supp. 669, 674 (S.D. Cal. 1949). The court has at times raised, but has never resolved, the question whether the rule of Strawbridge v. Curtiss is one of constitutional necessity or merely one of statutory interpretation, e.g., Treinies v. Sunshine Min. Co., supra.

${ }^{8}$ Neirbo Co. v. Bethlehem Corp., 308 U.S. 165, 169 (1939); Louisville Railroad Co. v. Letson, 43 U.S. (2 How.) 497 (1844). 
ciation members, each member being treated as a party individually. ${ }^{0}$ Thus, if a resident of Oregon wishes to bring an action not based upon federal law against a California association, jurisdictional limits will render the federal courts unavailable to him if any association members are residents of Oregon, unless he brings the action as a class suit against a representative member who is a resident of a state other than Oregon. ${ }^{10}$ Of course, if the latter course is chosen, all of the procedural problems attendant to a suit against an unincorporated association in the association name will be avoided. Moreover, it is theoretically conceivable that if the proper state law governing the attributes of an unincorporated association vests it with all of the incidents of a separate jural entity possessed by a corporation, a federal court may characterize and treat it as such for purposes of jurisdiction. ${ }^{11}$

\section{For Purposes of Litigating Capacity}

Although at common law the unincorporated association could not sue or be sued as an entity, ${ }^{12}$ the Supreme Court held in United Mine Workers $v$. Coronado $\mathrm{Co} .,^{13}$ where jurisdiction was based on a claim arising under federal law, that a labor union could be sued in its own name. The Coronado decision seems to have been predicated largely upon the ubiquity of federal substantive law respecting labor organizations; however, Rule 17(b) of the Federal Rules of Civil Procedure ${ }^{14}$ adopted and broadened ${ }^{16}$ this con-

\footnotetext{
O Levering \& G. Co. v. Morrin, 61 F.2d 115 (2d Cir. 1932), aff'd, 289 U.S. 103 (1933) (labor union); Raphael v. Trask, 194 U.S. 272 (1904) (partnership); Great Southern Fire Proof Hotel Co. v. Jones, 177 U.S. 449 (1900) (limited partnership); Ex parte Edelstcin, 30 F.2d 636 (2d Cir. 1929), ceri. denied, 279 U.S. 851 (1929) (actors' association).

10 The rigors of the restrictive procedural rules in regard to unincorporated associations are mitigated somewhat by the ready availability of the class suit both under FED. R. CIV.P. 23 and under many state statutes. See 3 Moore, Federal Practice fII 23.08, 23.13 (2d ed. 1948); Clark, Code Pieadng 397 (2d ed. 1947).

'11 See Puerto Rico v. Russell \& Co., 288 U.S. 476 (1933), where the court held that a sociedad en comandila, a form of Puerto Rican limited partnership, was an entity for jurisdictional purposes, basing the decision on an interpretation of civil law. Note, 33 Corux. L. REv. 540 (1933).

12 Moffat Tunnel League v. U.S., 289 U.S. 113, 118 (1933) ; Brown v. United States, 276 U.S. 134, 141 (1928).

13259 U.S. 344 (1922).

14 FED. R. Crv. P. 17(b): "Capacity to Sue or Be Sued. The capacity of an individual, other than one acting in a representative capacity, to sue or be sued shall be determined by the law of his domicile. The capacity of a corporation to sue or be sued shall be determined by the law under which it was organized. In all other cases the capacity to sue or be sued shall be determined by the law of the state in which the district court is held, except (1) that a partnership or other unincorporated association, which has no such capacity by the law of such state, may sue or be sued in its common name for the purpose of enforcing for or against it a substantive right existing under the Constitution or laws of the United States, and (2) that the capacity of a receiver appointed by a court of the United States to sue or be sued in a court of the United States is governed by Title 28 U.S.C. $\$ \$ 754$ and 959 (a)."

${ }_{15} \mathrm{~A}$ study of the cases would seem to indicate that Rule 17(b) went further than preexisting case law. E.g., Moffat Tunnel League v. U.S., 289 U.S. 113, 118 (1933), where the court said that an unincorporated voluntary association organized for the purpose of assisting in the development of commerce had no capacity to sue: "These leagues are not corporations, quasi-corporations, or organized pursuant to or recognized by any law ... and, unless authorized by statute, they have no capacity to sue ...." Sce also Sutherland v. United States, 74 F.2d 89 (8th Cir. 1934), where the court said that the Coronado case did not apply to partnerships.
} 
cept to provide that a "partnership or any other unincorporated association" could sue or be sued in its conimon name where the claim asserted was based on federal law.

In diversity suits, however, rule $17(\mathrm{~b})^{16}$ provides that the court must look to the law of the forum ${ }^{17}$ to determine whether the association is suable as an entity. Although a number of states have provided for suits against partnerships, unions, and other associations in the organization nanie, ${ }^{18}$ and others allow an action to be brought against one of the association members as a representative of the aggregate, ${ }^{10}$ many states require actions against such association to be brought against the individual members, all of whom must be joined and served with process. ${ }^{20}$

\section{For Purposes of Venue}

Federal law, then, regards unincorporated associations as aggregates for jurisdictional purposes, ${ }^{21}$ regards them as entities for purposes of capacity to litigate in cases arising under the auspices of federal question jurisdiction, and in diversity cases refers the capacity question to state law. ${ }^{22}$ It is little wonder that choosing among these approaches for the purpose of applying the general venue statute should prove a dilemma. Of course, if all of the members of the association are residents of the district in which the suit is brought, the determination of this matter will be unimportant. However, in the vast majority of cases this point will be crucial, for under subsections (a) and (b) of 28 U.S.C. $\$ 1391$ venue may be laid properly only in the district of residence of "all defendants." 23

16 See note 14 supra.

17 Presumably the reference is to the whole law of the forum including its conflict of law rule. Klaxon Co. v. Stentor Co., 313 U.S. 487 (1941) ; Erie R. Co. v. Tompkins, 304 U.S. 64 (1938).

18 At least twenty state legislatures have accorded litigating capacity to most types of associations: Ara. Code ANx. tit. 7, § 142 (1940); CAL. Code Crv. Proc. \$ 388 [For a discussion of substantive liabilities of unincorporated associations in California, see Comment, 42 CaIrF. L. Rev. 812 (1954)]; Colo. Rev. Stat. Anv. rule 17(b) (1953); Conn. Gen. Stat. § 7797 (1949); Des. Code ANN. tit. 10, §3904 (1953); IDAHO CODE ANN. § 5-323 (1947); MD. ANN. Code art. 23, \$134 (1951); MICE. Contr. Laws \$ 612.12 (1948); Mont. Rev. Codes ANN. § 93-2827 (1947); NEB. Rev. StaT. § 25-313 (1943); Nev. CoMr. Laws § 8564 (1929); N. J. Star. ANN. \& 2A:64-1 (I952); N.M. Star. ANN. \$\$ 51-18.5, 21-6-3 (1953); N. C. Gen. Stat. $\S 1-97(6)$ (1953); N.D. Rev. Code § 45-0401 (1943); Orra. Stat. tit. 12, § 182 (1951); Tex. Rev. Crv. Stat. rule 28 (1948); Utä Code AnN. rule 17(d) (1953); VA. Code ANN. \$ 8-66 (1950). And two jurisdictions have held associations suable as a inatter of public policy without enabling legislation. Busby v. Electric Utilities Employees Union, 147 F.2d 865 (D.C. Cir. 1945) ; Labonite v. Cannery Workers Etc. Umion, 197 Wash. 543, 86 P.2d 189 (1938). Several other states have extended litigating capacity just to partnership associations, E.g., N. Y. Crv. Prac. ACr \$ 222-a, OHIO Rev. COde ANN. § 2307.24 (Baldwin 1953) ; PA. Star. AnN. tit. 59, § 361 (1930).

10 New York, for example, allows an association to sue or be sued in the name of the president or treasurer. N. Y. GEN. Ass'Ns. LAw $\$ 13$. Nearly two-thirds of the states have statutes providing for class suits. See ClaAk, Code Preading 398 (2d ed. 1947).

20 FED. R. Crv. P. 4(d) (3) requires the manner of service to be made in accordance with state law.

21 See cases cited in note 9 supra.

22 See note 14 supra.

23 The present statute codifies the rnle developed when the statute was less explicit. Camp v. Gress, 250 U.S. 308 (1919). See note 1 supra for quotation of statute. 
The most provocative opinion to date was rendered by Judge Learned Fland in Sperry Products v. Association of American R.R., ${ }^{24}$ where jurisdiction was based on a claim under federal law rather than upon diversity. The court reasoned that the rule of the Coronado case $\mathrm{e}^{25}$ that associations are entities for purposes of suit in federal question cases should be extended to other procedural incidents and, accordingly, that the association was an entity for venue purposes with a residence separate and distinct from those of its members. ${ }^{26}$

Since there was no federal statute or Supreme Court ruling directly determinative, and since reference to state law is not compelled in federal question litigation, the court in Sperry Products was free to fashion its own solution to the federal venue question. It is true that a strict adherence to common law precedent would have called for the opposite conclusion; however, Sperry Products is consonant with the progressive trend of the law in procedural matters as exemplified by the Federal Rules and seems to be the proper solution under the circumstances. Indeed, it would be subversive of the policy of rules 4 (d)(3) 27 and 17 (b) to allow an association to be served with process and brought into court as an entity only to be dismissed on motion because an association has a different identity for venue purposes. When a federal court must exercise an unguided choice among possible procedural alternatives, it appears entirely appropriate to refer to the procedural temper of the times rather than to hearken back to outmoded common law sources. ${ }^{28}$ As a practical matter, the entity concept espoused in Sperry Products has been accepted as the only logical alternative by the other courts that have dealt with this problem in federal question litigation. ${ }^{28}$

The entity problem is compounded by doubts as to whether state or federal law is applicable where, as in Portsmouth Baseball Corp. v. Frick, jurisdiction is based on diversity of citizenship and the action is brought

24132 F.2d 408 (2d Cir. 1942), cert. denied, 319 U.S. 744 (1943).

25 United Mine Workers v. Coronado Co., 259 U.S. 344 (1922).

26 But of. Sutherland v. United States, 74 F.2d 89 (8th Cir. 1934), where the court applying federal law determined that a partnership was not an entity for purposes of venue. Coronado was distinguished as inapplicable to partnership associations. Although this view has been criticized as unworkable by leading commentators, e.g., 3 MOORE, Federat PRACTICE 1415 (2d ed. 1948), and rejected by most courts that have considered it, e.g., Thermoid Co. v. United Rubber Workers of America, 70 F. Supp. 228 (D. N.J. 1947), and although conceivable distinctions between labor umons and other kinds of associations have been blurred by rule 17(b), the Sutherland view was cited with approval in Koons v. Kaiser, 91 F. Supp. 511, 515 (S.D.N.Y. 1950).

27 FED. R. Crv. P. 4(d) (3) provides for service of process upon a partnership or other unincorporated association which is subject to suit under a common name.

28 See Francis v. Southern Pacific Co., 333 U.S. 445, 451 (1948) (dissenting opinion by Mr. Justice Black).

29 Brotherhood of Locomotive Firemen, Etc. v. Graham, 175 F.2d 802 (D.C. Cir. 1948), reversed on other grounds, 338 U.S. 232 (1949); McNutt v. United Gas, Cole \& Chemical Workers, 108 F. Supp. 871 (W.D. Ark. 1952); Griffin v. Illinois Cent. R. Co., 88 F. Supp. 552 (N.D. III. 1949) ; Salvant v. Louisville \& N.R. Co., 83 F.Supp. 391 (W.D. Ky. 1949); Thermoid Co. v. United Rubber Workers of America, 70 F. Supp. 228 (D. N.J. 1947). 
at the residence of the association. ${ }^{30}$ Does a logical application of either $17(\mathrm{~b})^{31}$ in the liglit of the Sperry Products approach or of Erie R. Co. v. Tompkins ${ }^{32}$ bind the federal courts to a consideration of state law? If so, does this call for an application of the state concept of litigating capacity to the federal venue statute or an analysis of the applicable state law to determine whether the action would be barred in the state courts?

Although a perfunctory application of the abstract federal concept as deliniated in Sperry Products would lead to an automatic classification of the association as an entity, it seems doubtful that this would be a logical application of the law as advanced in the Sperry case. Since that decision was predicated on the entity concept for litigating capacity found in 17 (b), a logical transfer of the Sperry approach to diversity cases [where 17(b) directs the courts to state law to determine the question of litigating capacity] would call for a solution of the venue problem in accordance with the same state concepts.

Whatever the applicability of 17 (b), the inference from the gloss upon the Erie doctrine would seem to call for a careful examination of the state law, for it is doubtful if the action can be brought in a federal court if the foreign residence of some association member closes the doors of the state court across the street. ${ }^{33}$

The extent to which state law is applicable should depend upon the reason for applying it. If it is applied for the purpose of conforming with the state law referred to in $17(\mathrm{~b})$, it should be sufficient to determine whether the applicable state law characterizes the association as an entity for purposes of litigating capacity. This solution seems to have been adopted in Darby v. Philadelphia Transp. Co., ${ }^{34}$ where the court ruled that since the Pennsylvania Rules of Civil Procedure have established the partnership as an entity for purposes of litigating capacity and service of

3028 U.S.C. $\$ 1391$ (a) provides that a diversity suit may be brought in the judicial district "where all plaintiffs or all defendants reside." Presumably the plaintiff can avoid the special venue problems inherent in a suit against an unincorporated association by bringing the suit in his own district of residence. But cf. Harrison v. Robb Mfg. Co., 110 F.Supp. 848 (D.Md. 1953) and Goldstein v. Chicago, R.I. and P.R. Co., 93 F. Supp. 671 (W.D. N.Y. 1950), where defendant corporation could not be sued in the district of plaintiff's residence in a diversity suit because the corporation were not doing business there. These decisions may have been based on a questionable interpretation of $\S 1391$ (c) as a limitation on $\S 1391$ (a). Note, 30 Inv. L.J. 324, 329 (1955). The suit must be brought in defendant's district of residence, however, if the plaintiffs are residents of different districts or if service of process cannot be obtained in plaintiff's district.

31 The reference here is to the portion of rule 17 (b) which directs the federal courts to state law to determine capacity to sue in diversity suits.

32304 U.S. 64 (1938).

33 "Angel v. Bullington [330 U.S. 183 (1947)] in its alternative ground followed the view of Guaranty Trust Co. v. York, 326 U.S. 99, 108, that for purposes of diversity jurisdiction a court is, in effect, only another court of the State . . . . . The York case was premised on the theory that a right which local law creates but which it does not supply with a remedy is no right at all for purposes of enforcement in a federal court in a diversity case; that where in such cases one is barred from recovery in the state court, he should likewise be barred in the federal court . . . W" Woods v. Interstate Rcalty Co., 337 U.S. 535, 538 (1949). See HarT \& Wechsler, The Federal Courts and the Federal Systemi 668-72 (1953).

3473 F. Supp. 522 (E.D. Pa. 1947). 
process, it should be so considered for federal venue purposes in a diversity case. The result reached in Koons $v$. Kaiser ${ }^{35}$ another diversity case involving a partnership in which the court purported to look to state law because of $17(\mathrm{~b})$, seems questionable. The court held that although the state legislature had accorded the partnership litigating capacity, ${ }^{30}$ it had not characterized it as an entity with a residence separate and apart from its membership; therefore, since all of the members were not citizens of the district, venue was improper. The fact that the state had given the partnership litigating capacity called for the opposite result if the court was considering state law because of 17 (b). There is nothing in 17(b) or Sperry Products that calls for an analysis of state law generally.

If the reason for applying state law is based on Erie, this question may often be more complex. Since the Koons court should not have considered state law to the extent they did on the grounds of 17 (b), perhaps the court felt impelled by Erie to look to the more general state law classification. Yet, if the court had gone further and examined the New York venue provisions, it would have found that a partnership can bring an action in the county where any one of the partners resides or, if all of the partners are nonresidents, in any county. ${ }^{37}$ Consequently, the action could have been brought in the "court across the street," and to the extent that the choice of state law may have been impelled by Erie, it would seem to have been misapplied.

In the Frick case, in contrast to Koons and Darby, the court made no reference at all to state law, indicating its conclusion that federal concepts were controlling. In looking to federal law to determine whether the associations were to be treated as entities, the court focused upon and adopted the affirmative answer which Sperry had given in a different jurisdictional context. The end result of the Frick analysis is this: In a diversity suit against an unincorporated association, supposing complete diversity and service of process on each of the parties, venue will be proper in any district or districts where the association may be said to reside; and this result will obtain regardless of whether, pursuant to the governing state law referred to by 17(b), the association can be sued or served as an entity.

Inasmuch as it seems desirable to sue unincorporated associations in the same manner as corporations and to obliterate technical procedural roadblocks wherever possible, the Frick result is commendable. However, since the association is regarded as an entity for venue purposes because it has been so characterized for purposes of litigating capacity, to characterize it thus in diversity cases where it lacks litigating capacity is logically untenable. Furthermore, this position ignores the possibility of an Erie

35 91 F. Supp. 511 (S.D.N.Y. 1950).

36 N.Y. CIV. PRAC. ACT $\$ 222-$ a provides that partnerships may sue and be sued in their partnership name.

37 N. Y. Crv. Prac. ACT $\$ 182$; Searle v. Foltis-Fischer Corp., 246 App. Div. 620, 282 N.X. Supp. 981 (1935). 
problem, although it may be tantamount to an assertion that Erie is not applicable.

The more logical solution in diversity cases calls for application of the state law respecting litigating capacity in order to carry over the substance rather than merely the form of the Sperry Products approach. Then, in those cases where entity treatment is proper, state law should be examined anew to the extent that Erie requires in order to determine whether local concepts in their totality would enable suit to be brought against the particular entity in the state courts located within the district.

\section{VENUE-PLACE OF RESIDENCE OF THE UNINCORPORATED ASSOCIATION}

Once it has been determined that under the applicable federal or state law the association is an entity, and that Erie is not a bar to the suit in diversity cases, whether the jurisdiction is based on a federal question or diversity should be irrelevent to the resolution of the residence problem, and federal law should control. ${ }^{38}$ Consequently, it is not necessary to treat the two classes of cases separately in the ensuing discussion.

Assuming that a defendant association is treated as an entity having a residence separate and apart from those of its members, as apparently it should be in federal question hitigation and often may be in diversity litigation, where is that residence located ${ }^{39}$ Prior to the Frick decision all recent cases dealing specifically with this question determined that the residence was located at the principal place of busmess of the association. ${ }^{40}$

This point was initially decided in Sperry Products under a special venue statute which provided for suit ". . . in the district of which the defendant is an inhabitant or in any district in which the defendant, whether a person, partnership or corporation, shall have committed acts of infringement and have a regular and established place of business." ${ }^{41}$ The court said that since a corporation was an inhabitant only of the district of its principal place of business within the state of its incorporation, the association should be similarly regarded. ${ }^{42}$ Consequently, it too could be sued

38 There is always a question of the applicability of Erie in a diversity suit, but anyone who admits to any kind of a procedural limitation to that doctrine should be expected to concede its inapplicability here. The ultimate result of these suits will not be changed by admitting the cases to federal jurisdiction. Guaranty Trust Co. v. York, 326 U.S. 99 (1945). It is obvious that once a state court lias acquired jurisdiction over a foreign corporation it is not going to dismiss the action because the defendant has an out-of-state residence.

30 Although subsections (a) and (b) of 28 U.S.C. $\$ 1391$ (1952) designate the resident district of defendant as a proper forum for suit, and subsection (c) defines residence for a corporation, the statute does not tell us where the residence of an unincorporated association is located. See note 1 supra.

40 Brotherhood of Locomotive Firemen, Etc. v. Graham, 175 F.2d 802 (D.C.Cir. 1948), reversed on other grounds, 338 U.S. 232 (1949); Sperry Products v. Association of American R.R., 132 F.2d 40s (2d Cir. 1942); McNutt v. United Gas, Coke \& Chemical Workers, 108 F. Supp. 871 (W.D. Ark. 1952) ; Griffin v. Illinois Cent. R. Co., 88 F. Supp. 552 (N.D. Ill. 1949); Salvant v. Louisville \& N.R. Co., 83 F.Supp. 391 (W.D. Ky. 1949).

4128 U.S.C. $\$ 109$ (1940).

42 "In the case of a corporation we may assume that it can be an 'inhabitant' only of the state of its imcorporation, [citation omitted] but even so, that will not serve as a test if there be several judicial districts in that state. Since a corporation can have no other activities than occupational, we are forced to choose among these; and it seems to us that we can only choose that place where its principal activities take place: its principal place of business. If so, the same test must apply to an unincorporated association . . . " $132 \mathrm{~F} .2 \mathrm{~d}$ at 411. 
at its principal place of business or at any regular and established place of business where it had infringed. Subsequently, in Brotherhood of Locomotive Fireman, Etc. v. Graham, ${ }^{43}$ using the same rule regarding corporate inhabitance under the then existing general venue statute ${ }^{44}$ hiting suit to the district of the defendant's inhabitance, the court likewise analogized corporate residence to association residence. In neither of these cases was it necessary to determine whether the analogy was predicated upon the presumed functional similarity of the two types of organizations or upon a broad interpretation of the term "corporation" to include unincorporated associations; however, it seems reasonable to infer from the opinions that the former was controlling.

In 1948 the general venue statute was changed by the addition of section 1391 (c) ${ }^{45}$ providing that a corporation should be regarded for venue purposes as residing in any district where it is doing business. This change posed a new dilemma: Should section 1391(c) be construed to apply to associations when treated as entities? If not, should the residence of associations be fixed by apphication of the discarded principal place of business rule?

Prior to the Frick case three district courts ${ }^{46}$ applied the principal place of business rule under the new general venue statute, largely upon the authority of the Sperry and Graham cases and with virtually no discussion of the problems raised by the new statutory provisions. In Frick, however, this solution was specifically rejected. The court seemed to regard the analogy between corporations and associations as tantamount to equivalence and construed section 1391 (c), which gives corporations a venue residence wherever doing business, as applicable to unincorporated associations as well. ${ }^{47}$

It must be recognized that the Frick solution to the residence problem

43175 F.2d 802 (D.C. Cir. 1948). The Graham case was decided under the old judicial code, but the court said in a footnote that "the rephrasing in 28 U.S.C. $\$ 1391$ (b) (1948) of 28 U.S.C. \& 112 (1946) makes no substantive change in respect to venue of the United States Courts generally." Id. at 804 .

Referring to this footnote, the court in Frick said: "The Court of Appeals simply shut its eyes to subdivision (c) of section 1391 which gives express permission for suit against a corporation in any judicial district where it is doing business ... .

"I camnot believe that that statement represents the Court's mature and considered appraisal of the new legislation. It must have been the result of inadvertence." 132 F. Supp. at 926. See note 1 supra.

4428 U.S.C. $\S 112$ (1946).

45 See note 1 supra.

46 McNutt v. United Gas, Coke \& Chemical Workers, 108 F. Supp. 871 (W.D. Ark. 1952) ; Griffin v. Illinois Cent. R. Co., 88 F. Supp. 552 (N.D. Ill. 1949); Salvant v. Louisville \& N.R. Co., 83 F.Supp. 391 (W.D. Ky. 1949).

47 It is possible that the Frick court was influenced by the fact that Sperry Products apphed the expanded portion of the special venue statute involved (see note 41 supra and related text) to unincorporated associations, a logical corollary being that the expanded portion of the new general venue statute, i.e., $\$ 1391(\mathrm{c})$, also apphes to associations. This analysis overlooks the fact that the expanded portion of the special statute referred to defendants generally, whereas $\$ 1391$ (c) refers only to corporations. 
is extreme. ${ }^{48}$ It is one thing to determine that the principal place of business cases like Sperry Products are not convincing authority in the light of the new corporate venue provisions, and that the mode of determining the associations' residence under the new statute must be re-examined. It is quite another to move from this premise to the conclusion that Congress must have intended the new corporate residence provisions to apply to unincorporated associations as well.

A search for evidence of Congressional intent behmd section 1391 is singularly unrewarding, and it seems not unfair to conclude that there was no specific intent regarding the status of unincorporated associations. ${ }^{40}$ Consequently, in this void the bold statutory construction of the Frick court may be justified.

The presumed Congressional intent behind the adoption of section 1391(c) was to modify the common law rule that placed the residence of a corporation in the state of its incorporation ${ }^{50}$ and to codify and liberalize the rule of the Neirbo case, ${ }^{51}$ which held that a corporation waived its venue privileges by filing to do business in a state and authorizing an agent for service of process. But what is to be made of the Congressional failure to mention unincorporated associations? There seem to be only three possibilities: (1) the old common law rule holding that associations have no residence apart from their individual members obtains; ${ }^{52}$ (2) the resi-

48 Compare the following language with the Frick view: "This may be a good argument to advance to a committee of Congress to urge an amendment to the general venue statute, but it does not justify the court in reading into the present statute virtue or lack of virtue which it does not have." Salvant v. Louisville \& N.R. Co., 83 F.Supp. 391, 396 (W.D.Ky. 1949). "The requirement of venue is specific and unambiguous; it is not one of those vague principles which, in the interest of some overriding policy, is to be given a 'liberal' construction." Oiberding v. Mlinois Central R. Co., 346 U.S. 338,340 (1953).

40 The Reviser's Note following 28 U.S.C. \$ 1391 (1952) does not mention that subsection (c) is an innovation. A study of the House Judicial Committee Hearings produces no more than a few comments to the effect that there were no "substantial" or "controversial" changes made in title 28. Professor Moore, who served as special consultant to the Advisory Committee was quoted as follows: "Venue provisions have not been altered by the revision. Two changes of importance have, however, been made ...." The two sentences seem contradictory, but, if Professor Moore considered \$1391(c) "important," he did not mention it at that time. Hearings Before Subcomnittee No. 1 of the Committee on Judiciary on H.R. No. 1600 \& H.R. No. 2055, 80th Cong., 1st Sess. 29 (1947).

In his treatise Professor Moore at least implies that umincorporated associations were not impliedly included in $\$ 1391$ (c): “ . . . and the theory of Neirbo will continue to be important where the defendant is an individual, partnership, or unincorporated association and consents to be sued in a state where he or it does not have a residence." 3 MIOore, Federat Practice 2136 (2d ed. 1948). If $\$ 1391$ (c) does apply to unincorporated associations, the rule of Neirbo is not necessary since the consent of Neirbo is the act of registering to do busmess in the state.

50 Southern Pacific Company v. Denton, 146 U.S. 202 (1892).

51 Neirbo Co. v. Bethlehem Corp., 308 U.S. 165 (1939). That improper venue is waivable by the defendant has long been the rule, and in Ex parte Schollenberger, 96 U.S. 369 (1878), it was lield that a foreign corporation's consent to receive state process was consent to be "found" in the state as provided in the general venue statute, 18 Stat. 470 (1875). This decision was nullified by a new venue statute, 25 STar. 433 (1888) which eliminated the word "found." The Neirbo case reactivated the reasoning of Ex parte Schollenberger without relying on the word "found."

52 See note 9 supra. 
dence has become unalterably fixed at the principal place of business; (3) the courts will continue to determine the residence of associations by the analogy to corporations. ${ }^{53}$ From these possibilities, perhaps the choice of the Frick decision is most defensible.

First, it is extremely doubtful that the common law rule can stand in the face of Coronado. ${ }^{54}$ That decision would be meaningless if there were no proper federal courts in which associations might be sued; but this would be the result if the common law rule were applied to organizations having members in more than one state. ${ }^{55}$

Second, since the principal place of business rule was based on an analogy to corporations, it seems anomalous to continue to apply it when this rule is no longer applicable to corporations. This is especially true since there has been no Supreme Court ruling or Congressional mandate so fixing the residence of associations. ${ }^{56}$

Finally, if Congress can be said to intend anything by its silence, ${ }^{67}$ it would seem most logical to conclude that it has tacitly bestowed its blessings upon the corporate analogy being used by the courts, thus liberalizing the venue provisions for associations by implication of its affirmative action in regard to corporations.

John E. Sparks*

53 Of course, there is always the possibility that the court migbt elaborate a new test or a new place of residence for the association, but that would seem to be a considerably more flagrant example of judicial legislating than construing $\$ 1391$ (c) to include associations.

54 United Mine Workers v. Coronado Co., 259 U.S. 344 (1922).

5528 U.S.C. $\$ 1391$ (1952) provides that suit may be brought only in the disfrict where all plaintiffs or all defendants reside. See Camp v. Gress, 250 U.S. 308, 311 (1919).

56 It could be argued that since the residence of uuincorporated associations prior to the adoption of $\$ 1391$ (c) was a common law concept, and the Sperry analogy an extension thereof, the specific statutory enactinent superseding the common law in regard to corporations does not destroy the basis for or the validity of the Sperry analogy.

57 For a critical discussion of the legislative silence doctrine, see Note, 43 CarrF. L. REv. 907 (1955).

* Member, Second-Year Class. 